China Perspectives

$2011 / 3$ | 2011

Chinese Medicine: The Global Influence of an Evolving Heritage

\title{
Internationalisation of the Chinese Currency
}

\section{Michel Aglietta}

\section{OpenEdition}

\section{Journals}

Electronic version

URL: http://journals.openedition.org/chinaperspectives/5661

DOI: 10.4000/chinaperspectives.5661

ISSN: 1996-4617

Publisher

Centre d'étude français sur la Chine contemporaine

\section{Printed version}

Date of publication: 1 October 2011

Number of pages: $79-83$

ISSN: 2070-3449

\section{Electronic reference}

Michel Aglietta, «Internationalisation of the Chinese Currency », China Perspectives [Online], 2011/3 |

2011, Online since 30 September 2014, connection on 15 September 2020. URL : http:// journals.openedition.org/chinaperspectives/5661 


\title{
Internationalisation of
}

\section{the Chinese Currency}

\author{
MICHEL AGLIETTA*
}

$M$ oney is a fundamental attribute of power. Its international use depends on whether and how it is supported by a strong economy, which determines a substantial part of the resources of power (the other being the military). Given the resources, the operating power of money is closely linked to the strategic objectives of governments in international politics. The dynamic interaction amongst countries between resource changes (hard power) on the one hand, and policy doctrines on international governance (soft power) on the other hand, shapes the international monetary system.

China's ascent is disturbing in international relations, not only because it is catching up fast in hard power, but also because Chinese ideas of "human authority" in soft power, stressing international norm-binding in the pursuit of global harmony, is at odds with Western theories of international relations based upon the stabilising power of a single hegemon. ${ }^{(1)}$ The strategic move to internationalise the renminbi (RMB) is best understood within this alternative view. It is not being done to replace the dollar with the RMB as a new key currency, but rather to build up a large consensus to abolish hegemony altogether.

\section{The balance of forces between domestic constraints and foreign opportunities: Creation of the Hong Kong RMB market}

In October 2008, the apex of the first round of the financial crisis entailed a traumatic shock for so open a country as China. The wholesale dollar money market seized up entirely, leading to the collapse of international trade. The Chinese leadership was convinced that China should no longer trust in the robustness of international banks. Furthermore, having studied the lingering Japanese crisis, Chinese leaders correctly diagnosed that the financial crisis was the symptom of a much more serious phenomenon: the end of the credit-induced consumer spree that had boosted Western capitalism since the heyday of financial deregulation. The debt deflation process in Western economies will last for years. Therefore the export-led growth regime of the post-WTO decade will no longer support China's development. Foreign trade had to be redeployed partly to developing countries, China had to become the fulcrum of Asian integration, and trade relations had to be based on long-term contracts. On the financial side, long-term loans and a system of payments no longer based on the vagaries of the dollar should back the new phase of globalisation.

However, full RMB convertibility is far from being at hand. It must be preceded by the liberalisation of financial services and therefore of the whole structure of interest rates. Such a dramatic change cannot be accom- plished overnight, all the more given that local governments (especially counties and municipalities) are overwhelmed with debt. Interest rates cannot become market-determined before those debts are cleared and the solvency of local governments has been firmly consolidated. Meanwhile, monetary authorities have recourse to regulating bank lending rates and subjecting bonds to bank rates, so that the cost of public finance is minimised. Of course, this inefficient financial regulation is costly for the nation. Too low a cost of capital distorts investment patterns and fosters overcapacities in heavy industries. Regulated interest rates channel all financing into a handful of state-owned banks, which enjoy secure profit margins because household saving is poorly rewarded. They have no incentive for efficient risk management, without which the shock of capital liberalisation would be hazardous and might entail devastating losses, as happened in Japan and several European countries in the early 1990s.

The main reason for this dismal state of affairs is fiscal. Because China has no political consensus for agreed-upon rules to transfer fiscal revenues amongst regional and local governments, the latter suffer huge discrepancies between their fiscal resources and their commitments to provide basic public services. They are forced to indulge in heavy indebtedness, collateralised by speculative real estate values. This entails that fiscal reform is a prerequisite for domestic financial liberalisation. It is a thorny problem of economic policy that impinges on the political processes that determine the sharing of fiscal revenues amongst provinces and sub-provincial levels of government.

If full convertibility is a distant prospect in crowning comprehensive financial reform, the dearth of international means of payments in the last three months of 2008 triggered an abrupt slump in world trade that induced a severe contraction in economic activity. The shock convinced China's monetary authorities that the seizure of dollar liquidity was capable of upsetting the pattern of international payments. Was it advantageous to use the dollar as a third-party currency in China's foreign trade any longer?

It is the chosen vehicle currency for invoicing and settling trade only if the transaction costs in using the dollar, involving two currency conversions between the partners in trade, are lower than those incurred in choosing the currency of one or the other partner. Transaction costs can be lower using a vehicle currency because they depend essentially on the liq-

Professor of Economic Sciences at the University of Paris X Nanterre, Michel Aglietta is also an advisor to the CEPII.

1. The distinction between hard and soft power is deeply anchored in Chinese political philosophy from the great thinkers of the Warring Kingdoms era (479-221 B.C). A brilliant recent attempt to mobilise ancient political thinking in clarifying modern concepts of international regimes can be found in Yan Xuetong, Ancient Chinese thought, modern Chinese power, Princeton University Press, 2011. 
Table 1 - Projections of Chinese imports invoiced in RMB and RMB deposits in Hong Kong

\begin{tabular}{|c|c|c|c|c|c|}
\hline \multicolumn{6}{|l|}{ (Value in US\$ billions) } \\
\hline Year & 2011 & 2012 & 2013 & 2014 & 2015 \\
\hline Value of imports settled in RMB & 31 & 74 & 162 & 304 & 482 \\
\hline CNH deposits (scenario 1) & 32 & 67 & 141 & 272 & 475 \\
\hline CNH deposits (scenario 2) & 56 & 125 & 242 & 429 & 706 \\
\hline
\end{tabular}

Source: CEIC. Calculations: Standard Chartered Research.

uidity of the money market to which the partners in trade have access. The larger the volume of trade invoiced and settled in a vehicle currency, the lower the transaction costs and the broader the use of this currency in international commerce and finance. It means that dynamic increasing returns are path-dependent. Even when the shares of the issuing country of the key currency have been shrinking for a considerable time in world trade, the key currency goes on being used as a vehicle currency. While a currency has been accepted as a key currency in international payment, only a dramatic event that drastically reduces its liquidity can alter the pattern of international payments. The global financial crisis brought about that event.

A Chinese importer and a Brazilian exporter, for instance, might find it advantageous to invoice and settle trade in RMB, on the proviso that RMB deposits generated by the payment of Chinese imports could gain a competitive return before they were recycled in trade to pay for Brazilian imports of Chinese products. However, the domestic money market in China is closed to non-residents apart from a handful of QFIs (qualified foreign investors). This quandary could only be resolved if RMB-denominated financial assets were made readily available outside mainland China. Hong Kong is the ideal financial centre to manage the financial services induced by the incipient offshore RMB.

Therefore the contradiction between foreign opportunities and domestic constraints called for a dual market: creating a financial market based on the RMB offshore, called the CNH market, while keeping financial controls onshore. The CNH (Hong Kong-delivered Chinese Yuan) market would stem from invoicing and settling trade, so-called grassroots internationalisation, the underpinning of which was the system of payments.

The Chinese monetary authorities lost no time. In 2009 they launched the pilot system of invoicing and settling foreign trade in RMB. The system is located in the Hong Kong financial centre and is backed by a memorandum of understanding between PBOC (People's Bank of China) and the HKMA (Hong Kong Monetary Authority) to guarantee and regulate liquidity. Corporate and financial entities, even if not directly involved in trade

Table 2 -Yields on 2- to 10-year Chinese government bonds as of year-end 2010

\begin{tabular}{|c|c|c|c|c|}
\hline In \% & $\mathbf{2}$ years & $\mathbf{3}$ years & $\mathbf{5}$ years & $\mathbf{1 0}$ years \\
\hline Offshore & 1.6 & 1.0 & 1.8 & 2.5 \\
\hline Onshore & 3 & 3.25 & 3.8 & 3.95 \\
\hline Source: Reuters.
\end{tabular}

with the mainland, have been authorised to open RMB accounts with accredited depositary institutions in Hong Kong. It is the start of the $\mathrm{CNH}$ market, e.g., the market for offshore RMB financial assets.

\section{Functioning and equilibrium of the $\mathrm{CNH}$ market}

The incipient impetus for developing the $\mathrm{CNH}$ market is the settlement of Chinese imports invoiced in RMB. The size of the market and therefore the share of the RMB in global FX (Foreign Exchange) trade will depend primarily on the share of trade invoiced in RMB in China's imports. Scenario 1 assumes that the share of RMB invoicing in Chinese imports will increase from 1 percent in 2011 to 20 percent in 2015. Another source of liquidity in the $\mathrm{CNH}$ market might be a loosening of capital controls permitting funds from Chinese residents to flow out to Hong Kong. Table 1 sums up the results of the projections for both scenarios.

In scenario 1, a strictly limited number of banks with quotas, led by Bank of China (Hong Kong), are allowed to invest and borrow liquid funds on the onshore money markets in China to facilitate the settlement of international payments in RMB. Furthermore, willing foreign central banks can conclude swap agreements with PBOC to diversify a share of their FX reserves in RMB through buying government bonds on the onshore interbank market. In scenario 2, 1 percent of resident bank deposits are supposed to be allowed to flow abroad.

On the liquidity base so generated, the $\mathrm{CNH}$ market creates diversified investment products (Dim Sum Bonds) and derivatives (CNH deliverable forwards and cross-currency swaps) to allow foreign enterprises to issue debt in RMB and manage their foreign exchange risk. An impressive momentum will be triggered by the rise of the $\mathrm{CNH}$ market. Investment banks will strengthen their $\mathrm{FX}$ trading desks in Hong Kong and will nurture their staff (BBVA, HSBC, Standard Chartered, Deutsche Bank). A lucrative business for underwriting securities is opening up.

With this background, the development of the $\mathrm{CNH}$ market was driven by policy events and market reactions to them. In June 2010, both under intense US pressure and the lobbying of PBOC for more leeway in domestic monetary policy, the government abandoned the peg on the dollar and adopted an effective exchange rate benchmark. The expectation of RMB appreciation attracted demand by institutional investors all over the world, eager to put RMB assets in their diversified portfolios. This demand turned speculative in the fall of 2010 after the announcement of Quantitative Easing 2 by Ben Bernanke at the Jackson Hall Symposium at the end of August. 


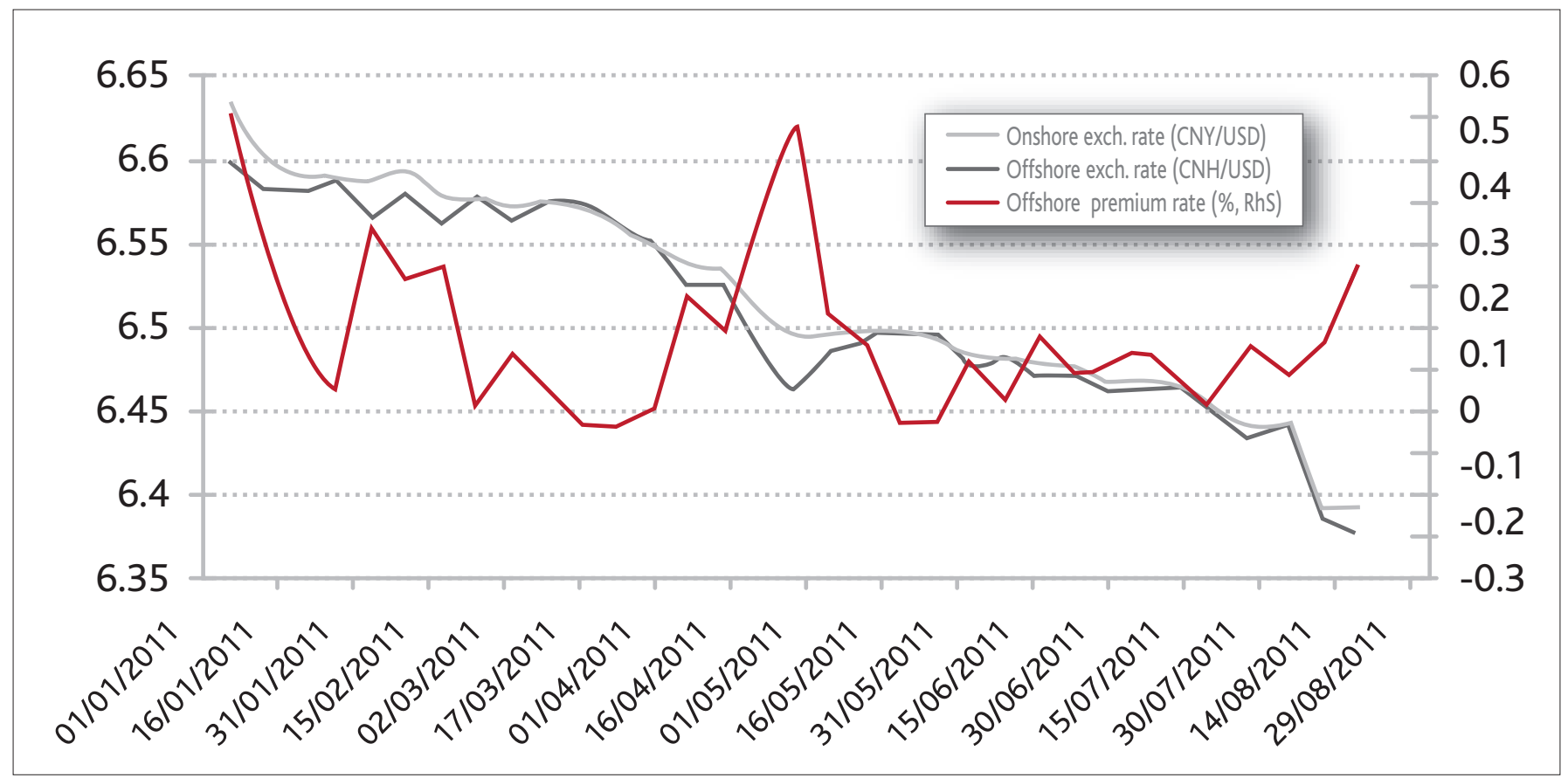

Source: Bloomberg.

The demand of market participants for a range of assets covering maturities and risk ratings competitive with other convertible currencies was met by Chinese monetary authorities who wanted to channel it to the Hong Kong market. To accommodate this demand, Chinese monetary authorities have generated a benchmark government bond yield curve in the Dim Sum bond market. In early December, the government issued RMB 8 billion worth of fixed-income securities at two, three, five, and ten-year maturities. In extending the yield curve to 10 years, the Chinese leadership signalled its will to incentivise international financial investors to invest in long-term financial assets. They have responded eagerly well ahead of issuers. Consequently, two- to ten-year bond yields in Hong Kong are much lower than the corresponding yields on similar government bonds sold to domestic investors on the mainland (table 2).

In August 2011, following a renewed episode of financial crisis in the US and in Europe, the Chinese government lost faith in the safety of its dollar assets. Determined to slow down its FX reserve accumulation, the government is encouraging domestic businesses to borrow RMB in Hong Kong to finance capital export outflows. To facilitate the issue of corporate bonds, on August 17 the government issued RMB 20 billion in sovereign bonds, 15 billion to institutional investors and 5 billion directed at retail investors. (2) The August 17 issue, which dwarfs the December 2010 issue, aims at creating a benchmark for the bond market and at reducing the spread between onshore and offshore rates in raising the supply of high-quality bonds available offshore.

Because liquid funds offshore and onshore are still imperfectly fungible, there are two spot FX markets in Hong Kong. The \$/CNY exchange rate for commercial transactions is benchmarked on the exchange rate of the onshore spot market, since the RMB is convertible in current accounts. The $\$ / C N H$ exchange rate for financial transactions unrelated to trade has a quotation and a liquidity of its own (figure 1).
Since capital controls hamper arbitrage between RMB offshore and RMB onshore, there are dual exchange rates. After the birth of the $\mathrm{CNH}$ market, a momentous demand arose for RMB assets in Hong Kong. An ensuing lack of liquidity appreciated the offshore exchange rate compared to the onshore rate. The offshore risk premium culminated around 2 percent. However, the strength of the RMB encouraged foreign exporters to invoice their exports to China in RMB. Their deposits in Hong Kong banks built liquidity surprisingly fast, so that the premium of the offshore yuan on the official rate closed near year-end 2010. (3) Recently the offshore premium widened again, signalling renewed pressure for a faster appreciation of the RMB. The deliverable forward market confirms the finding. It points to a wider expectation of appreciation of the RMB starting in early August, after the announcement of the downgrading of the US government debt rating and Ben Bernanke's declaration to keep short-term interest rates close to zero for a considerable time (figure 2).

In about one year, the process of financial opening has been put on track. It confirms the commitment of China's government to Hong Kong as a leading financial center in Asia. It will also contribute to slowing down foreign exchange reserve accumulation if it induces capital outflows by other agents than the central bank. It might occur via FDI outflows by domestic corporations financed in RMB or via trade credit by Chinese exporters able to invoice export contracts in RMB. Alternatively capital inflows will not trigger offsetting $\mathrm{FX}$ reserve accumulation by the central bank if progressively relaxed regulation permits foreign holders of RMB liquidity in Hong Kong to invest in mainland securities markets. The foreign holders will have bought Yuan against dollars abroad in the beginning. The resulting capital

2. In order to give weight to the move and to show its political importance, vice-Premier Li Keqiang went to Hong Kong to symbolically launch the massive issuance of RMB 20 billion in sovereign bonds.

3. In November 2010, non-resident deposits in the CNH market had already quadrupled from August. It does not mean that the market is arbitraged once and for all. The liquidity premium can still be volatile, as in late April and early May 2011, because the CNH market is not yet deeply entrenched. 
Figure 2 - China: spot and one-year RMB/USD exchange rate, offshore market

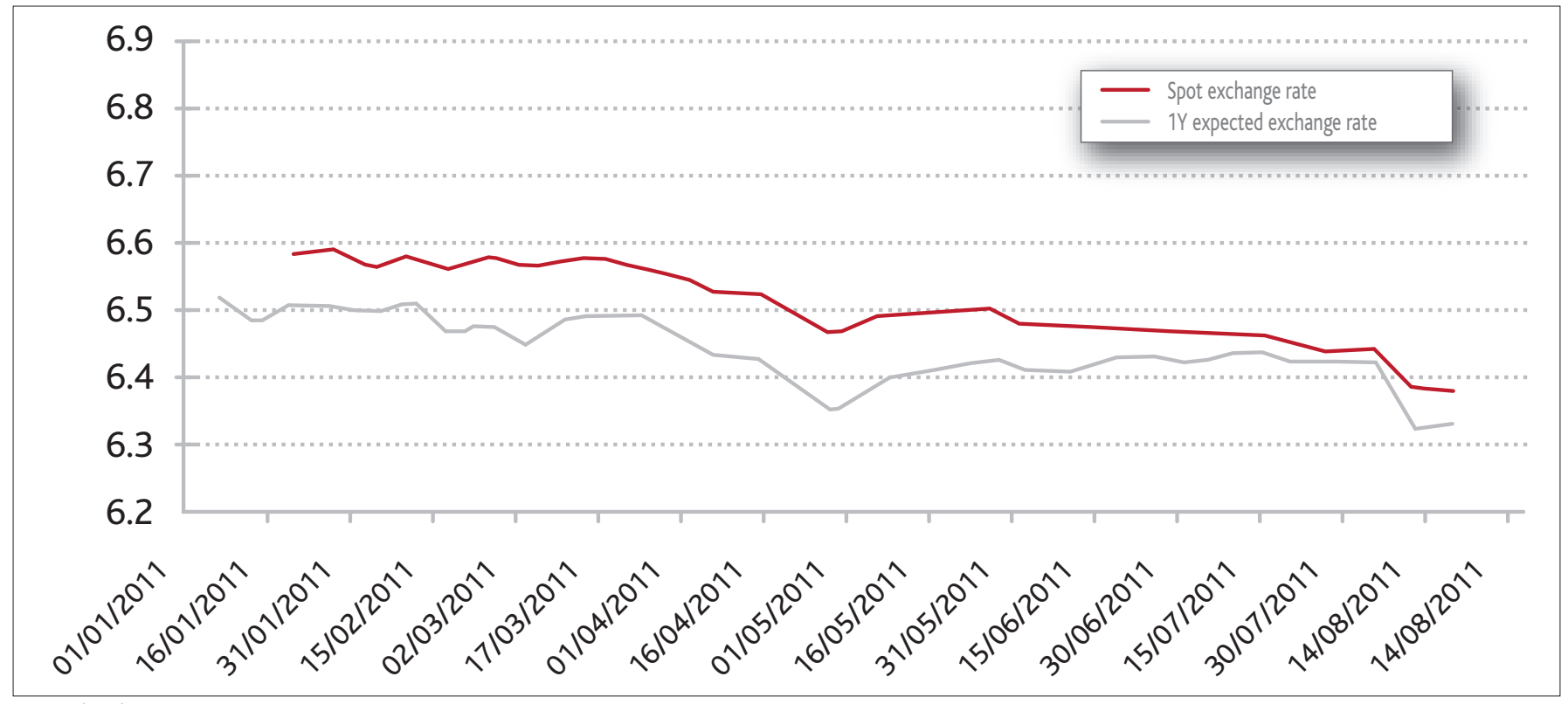

Source: Bloomberg.

inflows into China via Hong Kong will be offset by a capital outflows between Chinese and foreign banks. Alternatively, regulation can be progressively relaxed to permit holders of liquidity in Hong Kong to invest in mainland securities markets.

\section{The long-term significance of RMB internationalisation}

RMB internationalisation has significance both for capital allocation in the domestic economy and for the evolution of China's financial relations with the rest of the world.

Domestically, the PBOC wants to use the Hong Kong market as an indirect way to reform the domestic financial market. The allocation of capital will be transformed because of the internationalisation of the RMB. The reason is that the market in Hong Kong includes domestic financial institutions that have already issued corporate bonds in Hong Kong for domestic enterprises. This new opportunity for financing creates a link between domestic and foreign credit in RMB. It is one of the reasons why in 2011 the quantity of credit obtained by non-financial entities has been higher than the planned creditor aggregate determined by the central bank and higher than the aggregate of bank credit to the non-financial sector. Furthermore, because Chinese financial institutions will directly encounter international practices in risk management, they will become more risk-conscious.

One must understand that the issue of RMB convertibility is contentious amongst different power strongholds within the central government. On one side, the Ministry of Trade and the National Development and Reform Commission (NDRC) are growth-minded and much concerned about external competitiveness. They are allied with provincial officials alarmed at the slightest hint of rising unemployment, and with executives of SOEs, whose power is enhanced by high retention of earnings to be ploughed back into fixed capital accumulation. They make a powerful and influential lobby while growth shows signs of weakening. On the other side, the PBOC and other financial regulatory institutions are well aware that the mecha- nism for allocating savings in China and the excessive recourse to banks at the expense of capital markets entails a distorted allocation of saving and therefore widespread inefficiencies. Furthermore, the PBOC would appreciate greater access to interest rates as a channel for running monetary policy, whether or not this channel could impinge upon the full range of interest rates. The PBOC view has been strengthened by the threat of inflation. More flexible exchange rates, allowing monetary policy to focus on domestic objectives, would suit the PBOC very well. In launching the offshore program to internationalise the RMB while getting rid of the de facto peg on the dollar, the State Council has struck a compromise. It allows SOEs to finance their expansion abroad in the cheapest way possible for the purpose of becoming global corporations before 2015. It creates a potentially large international market for the RMB that enlarges its international use in trade and investment with other emerging market countries. Meanwhile it keeps the core of capital controls that preserves the dual market for interest rates. Capital controls might not reduce the magnitude of capital flows overall, but they shape their structure to discourage disruptive hot money and favour beneficial long-term flows. ${ }^{(4)}$

In international politics, RMB internationalisation pertains to a soft power strategy aimed at binding Asian countries into a regional zone of prosperity while reducing US interference. Expansion of intra-regional trade in East Asia and a large market in long-term bonds to finance mutually important infrastructure, energy, and primary resource supply will be facilitated by a large circulation of RMB in China's neighbouring countries. An increase of the RMB's share in basket currencies used by ASEAN countries might help stabilise the bilateral exchange rates between their own currencies and the RMB.

Those structural developments foster a gradual process for an exit from the key currency status of the dollar and contribute to a polycentric sys-

4. In conformity with the principle of incremental change, the PBOC issued a new regulation in mid-June 2011 on cross-border FDIs. The rule allows all foreign companies (including subsidiaries of Chinese firms incorporated in Hong Kong) to remit on the mainland in the form of FDls all funds raised on the offshore market. It is a big push for internationalising the RMB, which still protects the domestic market from many sources of speculative capital inflows. 
tem based upon a loose Asia-wide monetary area centred on RMB convertibility together with dollar and euro regions. The advantage of regional monetary zones is that they can manage financial disturbances within the region and prevent them from spilling over to the wider International Monetary System. An implicit subsidiary principle would apply.

Large and open regional economic zones can grasp the welfare gains of integration with proper cooperation. But the correlative move to a multipolar system will entail an asymmetrical competition between leading currencies that might exacerbate the present woes. Discordant economic policies will be under the fire of intense portfolio shifts, triggering much higher volatility in leading exchange rates. The lack of a global viewpoint on liquidity and the determination of an anchor to world prices will become more acute problems. At that point, China's plea for international governance based upon responsibility of the main powers exerted under mutually binding rules and upon the promotion of an international reserve asset might become credible. 